\title{
Germany's Strategy in Handling COVID-19: The Role of National Leadership Strength and The Maximization of Welfare State Continental System Support
}

Strategi Jerman Mengatasi Pandemi COVID-19:

\section{Peran Kekuatan Kepemimpinan Nasional dan Pemaksimalan Dukungan Sistem Welfare State Continental}

\author{
Siti R. Susanto \\ Universitas Airlangga
}

\begin{abstract}
ABSTRAK
Pandemi Covid-19 merupakan krisis kesehatan terbesar pada abad ke-21. Diawali dengan kemunculan virus flu jenis baru di Wuhan-China pada Desember 2019, virus ini menyebar ke seluruh dunia dengan sangat cepat sehingga mengakibatkan kematian yang tinggi d seluruh dunia. Jerman merupakan salah satu negara yang terdampak pada periode awal virus muncul di Eropa. Setelah menyadari efeknya fatal, Pemerintah Jerman melakukan kebijakan nasional integratif mengatasinya, hingga Jerman perlahan keluar dari krisis. Fenomena ini disebut dengan "German exception", karena banyak negara masih berjuang mengatasi pandemi. Paper ini meneliti strategi kebijakan nasional Pemerintah Jerman mengatasi Covid-19. Kerangka pemikiran yang dipakaiadalah teori kepemimpinan nasional di masa krisis dan peranan sistem welfare state nasional. Argumen yang menentukan keberhasilan Jerman mengatasi Covid-19 adalah peran kepemimpinan nasional Kanselir Merkel yang visioner dan konsisten di masa krisis, serta dukungan sistem welfare state Continental yang dianut negara sehingga menguatkan masyarakat dan kestabilan politik nasional di masa pandemi.
\end{abstract}

Kata-kata kunci: Jerman, Covid-19, kepemimpinan nasional, Kanselir Merkel, sistem welfare state Continental.

The Covid-19 pandemic is the biggest health crisis of the 21st century. Starting with the emergence of a new type of flu virus in Wuhan-China in December 2019, this virus has spread throughout the world very quickly and resulting in high deaths worldwide. Germany was one of the countries affected in the early period when the virus emerged in Europe. After realizing its fatal effects, the German Government carried out an integrative policy to overcome it until the German national came out of the crisis. This phenomenon is called the "Germany exception", as many countries are still struggling with the pandemic. This paper examines the German Government's national policy strategy to tackle Covid-19. The framework used is the theory of national leadership in times of crisis and the role of the national welfare system. The arguments that support Germany in overcoming Covid-19 are the role of Chancellor Merkel's national leadership, who is visionary and consistent in times of crisis and support for the welfare system of the Continental state is a state that strengthens society and national political stability during the pandemic.

Keywords: Germany, Covid-19, national leadership, Chancellor Merkel, continental welfare state system. 
Pandemi Covid-19 merupakan krisis kesehatan terbesar pada abad ke-21, diawali kemunculan virus flu jenis baru mematikan di Wuhan, China pada Desember 2019. Selanjutnya, virus ini menyebar ke seluruh dunia, sehingga sampai pada 4 Juli 2020, World Health Organization (WHO) mencatat jika terdapat lebih 10 juta kasus di 216 negara/teritori, dengan jumlah kematian mencapai lebih dari setengah juta jiwa (WHO 2020). Covid-19 telah mempengaruhi kedaulatan dan stabilitas negara di seluruh dunia, terutama dalam aspek pertahanan dan keamanan. Hal ini juga dialami Jerman yang memiliki kasus penularan dan kematian signifikan di Uni Eropa (UE) di masa awal penularannya, bersama Italia, Spanyol, dan Perancis. Pada periode awal di Jerman, pemerintah tidak melakukan tindakan signifikan dalam menghadapi krisis, melainkan hanya berfokus memperlambat penularan dengan melakukan tes kepada warganya. Hal ini mirip dengan kondisi di level UE. Akibatnya, jumlah infeksi dan kematian di dua bulan pertama di Jerman sangat tinggi. Jerman mengalami puncak kasus pada April 2020 yang sekaligus masa terkritis negara tersebut.

Menariknya, grafik jumlah penularan dan kematian perlahan menurun stabil pada akhir April 2020. Meski pada 9 Agustus 2020, Jerman memiliki 215.891 kasus penularan dan 9.196 kematian (ECDC 2020), kondisi tersebut dinilai sukses meredam laju penularan dan kematian secara global (Bennhold 2020; Spahn 2020), mengingat Jerman merupakan negara paling padat di UE dengan 83.2 juta penduduk. Transformasi ini relatif cepat dibanding kemampuan negara-negara Eropa lain dan Amerika Serikat yang masih berjuang mengatasi pandemi. Fenomena keberhasilan Jerman ini disebut dunia dengan istilah "German exception" (Bennhold 2020). Awal Mei 2020, Jerman bertahap membuka fasilitas publik setelah sejak awal Maret 2020 melakukan pembatasan sosial ketat secara nasional. Paper ini meneliti faktor penting yang menentukan keberhasilan Jerman mengatasi Covid-19, khususnya mengurai kekhasan strategi pemerintah Jerman menghadapi krisis, sehingga membedakannya dari strategi negara lain. 


\section{Grafik 1 \\ Jumlah Penularan dan Kematian akibat Covid-19 di Jerman}

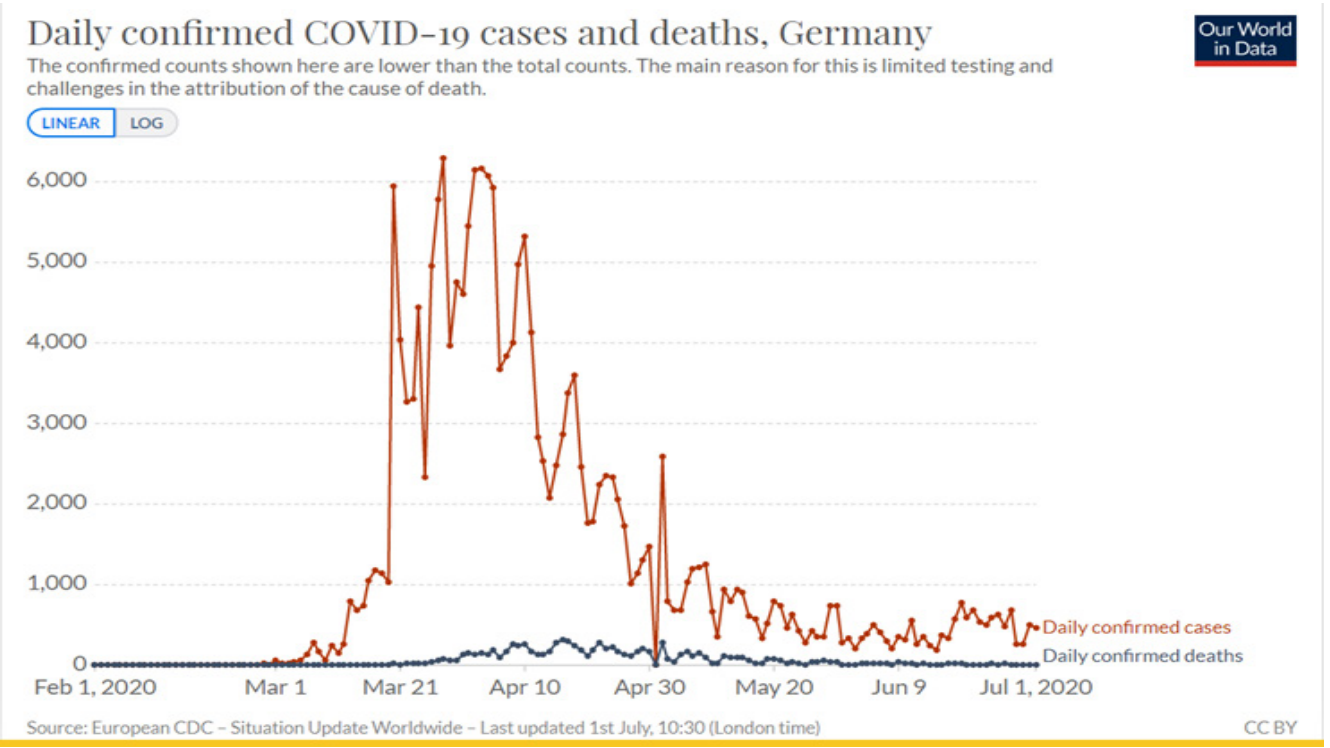

Sumber: Our World in Data (2020)

\section{Fenomena Covid-19 di Jerman dan Respon Pemerintah}

Kasus pertama Covid-19 di Jerman ditemukan pada 27 Januari 2020, setelah wisatawan Jerman kembali dari liburan musim dingin di Ischgl, Austria. Sejak saat itu, terjadi peningkatan penularan dan kematian per hari. Hal ini diperparah dengan ketidaksiapan pemerintah memprediksi bahwa negaranya akan menjadi salah satu pusat penyebaran terbesar virus di Eropa. Jumlah kasus terbanyak terjadi di negara bagian (Länder) Bavaria dan Baden Wüttenberg. Akibatnya, dua bulan awal kasus Covid-19 muncul, tidak ada langkah antisipasi penting pemerintah, selain memperlambat jumlah penularan, dengan melakukan testing, tracking, dan tracing (TTT) warga. Hal ini memicu protes publik yang menilai pemerintah lambat dan tidak siap mengantisipasi dampak Covid-19. 
Germany's Strategy in Handling Covid-19: The Role of National Leadership Strength and The Maximization of Welfare State Continental System Support

Merespons kondisi diatas, secara mendadak Kanselir Merkel melakukan pidato resmi kenegaraan di televisi nasional pada 18 Maret 2020 terkait pandemi Covid-19, termasuk strategi darurat nasional yang akan dilakukan. Pidato ini diluar kelaziman Merkel, yang selama 15 tahun sebagai kanselir biasanya berpidato di televisi nasional setahun sekali, yaitu menjelang tahun baru (Deutsche Welle 2020). Sebelum itu pula, pada 16 Maret 2020, pemerintah menyatakan penutupan sekolah serta fasilitas publik, dan penutupan perbatasan dengan negara tetangga (contact restriction) berdasarkan Undang-Undang Darurat Kesehatan (Gesundheitsnotstand) tahun 2001 (Binder dkk. 2020). Ini menandai dimulainya kebijakan karantina nasional di Jerman. Meskipun demikian, Merkel tidak menyatakan kondisi darurat nasional, seperti yang ditempuh Spanyol, Italia, Jepang, dan Amerika Serikat.

Berdasarkan laporan Oxford Martin School (Our World in Data 2020), pemerintah Jerman menerapkan empat langkah kebijakan nasional Covid-19, yang meliputi pencegahan (prevent), deteksi (detection), pembendungan (contain), dan pengobatan (treat); yang kemudian menjadi kunci keberhasilan German Exception. Pemerintah menunjuk Robert Koch Institute (RKI)-badan riset kesehatan nasional, sebagai mitra utama mengatasi pandemi. Pada 16 Januari 2020, RKI mulai melaksanakan TTT gratis kepada seluruh warga, disusul 16 Maret menutup perbatasan, dan menerapkan contact restriction nasional pada 22 Maret 2020 (Our World in Data 2020).

Dengan keseluruhan kebijakan pemerintah mengatasi Covid-19 tersebut, maka publik Jerman menilai jika pemerintahnya maksimal mencari solusi, dibuktikan dengan semakin menurunnya angka penularan dan jumlah kematian. Pada awal Maret 2020 tingkat kepercayaan masyarakat kepada pemerintah rendah, tapi kemudian menjadi meningkat pesat pada Mei 2020 (Euronews, 2020). 


\section{Kepemimpinan Nasional dalam Situasi Darurat dan Welfare State System}

Penjelasan dalam tulisan ini akan menggunakan teori peranan kepemimpinan nasional dalam situasi darurat dan sistem welfare state (WS) di Eropa. Teori kepemimpinan nasional pada kondisi darurat nasional menjadi variabel penting, karena meskipun Covid-19 merupakan isu global, namun dalam penanganannya masih sangat bersandar pada otoritas negara. Sementara, teori WS menjelaskan salah satu contoh keputusan besar pemimpin selama krisis pandemi, yang mana sistem WS sangat mempengaruhi dan menentukan dikeluarkannya kebijakan pemerintah dalam mengatasi krisis.

Berdasar konteks politik nasional dan internasional, krisis pandemi Covid-19 tergolong pada kondisi krisis/darurat (state of emergency). Hal ini terjadi karena wilayah terdampak sangat luas yaitu di seluruh dunia tanpa terkecuali dan ditambah dengan jumlah korban jiwa tinggi. Krisis tersebut menimbulkan kepanikan global di semua negara karena sifatnya mendadak, akibat virus jenis baru yang mematikan, sementara belum ada vaksinnya (Susanto 2020). Kondisi yang tidak menentu tersebut, didefinisikan Cliffe dan Luckham (1999) sebagai complex political emergency (CPE), yang ditandai dengan kondisi bahaya dan tingkat kematian tinggi sehingga berujung pada menghilangnya kekuatan negara, atau disebut fenomena governance failure. Pihak yang paling memiliki otoritas mengeluarkan status kondisi darurat adalah otoritas eksekutif (Cliffe dkk. 1999; Ferejohn dkk. 2004).

Selama ini, state of emergency lebih banyak disebabkan ancaman keamanan secara fisik, seperti perang dan konflik. Cliffe dkk. (1999) dan Ferejohn dkk. (2004), khusus menjelaskan jika penyebab kondisi darurat adalah konflik internal domestik. Namun, kenyataannya tidak terbatas ancaman fisik, tetapi terdapat pula ancaman yang non-fisik (intangible), disebabkan pandemi penyakit menular (DACF 2005; Magnusson 2017). Magnusson (2017) menyebutnya sebagai "public health emergency of international concern", yang terjadi karena kasus luar biasa penyakit menular, bencana alam, kontaminasi/radiasi nuklir/ senjata kimia/biologis. Magnusson (2017) mendefinisikan 4 
penyakit menular penyebab kondisi krisis yaitu: cacar (smallpox), severe acute respiratory syndrome (SARS), human influenza (sub-tipe baru), polio (virus tipe ganas). WHO meresponsnya dengan menetapkan standar kesehatan global yaitu International Health Regulation (IHR) tahun 2005.

Beberapa riset menganalisis bahwa terdapat hubungan erat antara figur kepemimpinan dan situasi krisis (Arenas dkk. 2017; Hume 1997). Menurut Hume (1997), kepemimpinan (leadership) adalah kemampuan pemimpin pemerintahan menjalankan fungsinya memenuhi kebutuhan dasar rakyat, yaitu keamanan dan kesejahteraan, serta mengatur hubungan internasional. Mengacu pada Cliffe dkk. (1999), dijelaskan jika keberhasilan pemimpin di masa krisis ditandai dengan teratasinya kondisi governance failure. Artinya, pemimpin harus bisa mengembalikan kondisi pemerintahan hingga bisa kembali berjalan normal. Hume (1997) mendefinisikan 3 modalitas pemimpin agar keluar dari krisis. Modalitas tersebut meliputi kapasitas (capacity) perangkat dan sumber daya pendukung; itikad (will) kuat, konsisten, dan komprehensif keluar dari krisis; dan visi (vision) mengarahkan semua elemen negara mencari solusi krisis.

Terkait tugas pemimpin yang paling mendesak selama krisis adalah memenuhi kebutuhan pokok masyarakat. Pada konteks negara tertentu, kemampuan negara tersebut secara spesifik tercantum pada undang-undang dasar (UUD), yang disebut sebagai sistem negara kesejahteraan. Dalam sistem WS terdapat jaminan komitmen negara memenuhi kebutuhan dasar dan kesejahteraan sosial masyarakatnya (Madison 1970). Sehingga terdapat hubungan yang erat antara situasi darurat nasional dengan sistem WS; atau dengan kata lain, WS merupakan salah satu kunci keluar dari krisis (Sandher dan Kleider 2020). Peran WS semakin penting mengatasi krisis nasional karena sistem tersebut sangat kuat merepresentasikan ideologi, politik, prinsip, dan karakter masyarakat suatu negara (Menachem 2015).

Berdasarkan sejarahnya, sistem WS bermula di Eropa ketika wilayah tersebut mengalami peningkatan ekonomi tinggi pasca Revolusi Industri pada abad 17. Ini kemudian berkembang serta terintegrasi dalam pemerintahan nasional pada pasca Perang Dunia II. Esping-Andersen (1990) menyatakan bahwa 
WS merupakan konsekuensi logis menguatnya pengaruh sistem kapitalisme (the logic of capitalism), yang menjunjung tinggi harmonisasi konsep kewarganegaraan-kelas, efisiensi-kesetaraan, serta kapitalisme-sosialisme. Salah satu karakter kuat sistem WS adalah keterlibatan negara dalam dinamika ekonomi nasional. Sistem WS merepresentasikan perspektif ekonomi Keynesian yang menggambarkan relasi konstruktif antara pemerintah dan kehidupan ekonomi (Kosonen 1995). Peran pemerintah berfokus pada pengaturan isu pengaturan upah tenaga kerja, keseimbangan faktor produksi dan pembiayaannya, serta tingkat produksi dan konsumsi. Sehingga perwujudan sistem WS Eropa tampak pada perlindungan dan kesejahteraan sosial masyarakat, memprioritaskan kebutuhan pokok masyarakat, mengutamakan penyediaan transfer pendapatan kepada masyarakat di masa tidak produktif (pensiun, PHK, hamil), pemberian program jaring pengaman sosial (antisipasi kemiskinan), memprioritaskan kepentingan perempuan dan keluarga, penyediaan pendidikan/ pelatihan kerja, serta fasilitas kesehatan (EASPD 2014; Scaratti dkk. 2018).

Namun berdasarkan praktiknya, model WS Eropa sangat beragam; tergantung pada pemerintah dan negaranya. Terdapat 5 model WS Eropa (Eichhorst dan Hemerijck 2008; Scaratti dkk. 2017) yaitu Scandinavian, Conservative Continental, Southern European, Anglo Saxon-Irish, dan Post-communist model. Pertama, Scandinavia model menekankan aspek egalitarianisme dan universalisme penyediaan kesejahteraan, sehingga menargetkan seluruh penduduk sebagai penerima fasilitas kesejahteraan sosial. Hal tersebut bersumber dari kondisi masyarakat Eropa Utara sebagai "work societies" yang mana terdapat kesetaraan antara perempuan dan laki-laki untuk bersama terlibat di sektor produksi (Kosonen 1995, 85). Sistem ini dianut negara-negara Skandinavia, seperti Denmark, Swedia, Norwegia, Finlandia, dan Islandia. Kedua, model conservative-continental atau model Bismarck, yang memiliki titik tekan hampir sama dengan model Scandinavia. Namun sistem ini tidak mengharuskan perempuan terlibat di sektor produksi sehingga sistem ini lebih mengandalkan pada peran pasar kerja. Pemenuhan kebutuhan sosial diatur negara dan lebih didominasi bantuan tunai langsung melalui program nasional, keluarga, dan kesejahteraan pekerja. Negara 
Germany's Strategy in Handling Covid-19: The Role of National Leadership Strength and The Maximization of Welfare State Continental System Support

yang menganut model ini adalah Jerman, Belanda, Perancis, dan Belgia.

Ketiga, model Anglo Saxon-Irish, atau liberal/common model. Dalam konteks ini, peran negara sangat minimal mendistribusikan kesejahteraan sosial, dan kalangan yang mendapat privilege ini adalah kelas pekerja saja, bahkan hanya terbatas pada kategori miskin. Sistem ini berlaku di Inggris dan Irlandia. Keempat, model Southern European atau model Mediterania atau periferi. Prinsip dasar model ini hampir sama dengan model Continental yang menekankan peran utama keluarga dalam memberikan perlindungan kesejahteraan sosial bagi mereka yang tidak/belum terserap pasar kerja. Dengan sistem pasar kerja yang terbatas, tunjangan kesejahteraan sosial hanya diperuntukkan bagi para pensiunan saja. Negara yang menganut sistem ini adalah Italia, Yunani, Spanyol, dan Portugal. Kelima, model post-communist/ Eropa Timur ditandai dengan semakin berkurangnya keterlibatan pemerintah dalam pemenuhan aspek kesejahteraan sosial rakyat, yang diikuti dengan pengurangan berbagai fasilitas sosial. Sebagai gantinya, kalangan swasta komersial hadir dan menjadi aktor baru.

\section{Kekuatan Kepemimpinan Merkel di Masa Krisis Covid-19}

Bagi kalangan penstudi HI dan politik Jerman, salah satu faktor kesuksesan Jerman mengatasi pandemi adalah terletak pada figur kepemimpinan Kanselir Angela Merkel. Dalam sejarahnya, Merkel merupakan pemimpin perempuan pertama sekaligus terlama kedua memerintah Jerman, setelah Kanselir Köhlmentor politiknya. Ini bukti tingginya kepercayaan publik kepada Merkel, sehingga ia digelari dengan Die Mutti, ibu rakyat Jerman. Berdasarkan teori kepemimpinan (Filippidou 2014), Merkel masuk dalam kategori pemimpin situational, yang mana kualitas kepemimpinannya dipengaruhi oleh pengalaman hidup, organisasi, dan lingkungan. Terdapat beberapa faktor situasional yang mengasah kepemimpinan Merkel. Pertama, latar belakang Merkel yang dibesarkan di lingkungan kontras, antara Jerman Barat dan Timur. Dilahirkan di Jerman Barat yang liberal, 
Merkel menghabiskan masa kecilnya hingga meraih Ph.D. Kimia Kuantum di Jerman Timur, yang saat itu merupakan wilayah pengaruh komunis Uni Soviet. Ia pun sering diawasi STASI, dinas intelijen Jerman Timur karena terlibat aktivitas pergerakan (Mills 2008). Alhasil, Merkel tumbuh sebagai ilmuwan sekaligus individu yang bisa beradaptasi dengan segala lingkungan, terlebih ia tinggal di "medan pertempuran" Perang Dingin. Setelah berkarir sebagai ilmuwan di Berlin, Merkel memutuskan masuk ke dunia politik, mengikuti pemilu legislatif Jerman Timur pasca Uni Soviet runtuh pada tahun 1989, dan ia terpilih sebagai ketua perlemen Jerman Timur. Menjelang bersatunya kembali Jerman Barat dan Timur (Reunifikasi Jerman) pada 1990, Merkel menjadi anggota Partai Kristen Demokrat (CDU) pimpinan Köhl. Saat Köhl terpilih sebagai kanselir, Merkel ditunjuk sebagai menteri termuda, membawahi urusan keluarga, perempuan, dan pemuda. Meskipun lama meninggalkan dunia ilmuwan, Merkel sangat kuat memegang prinsip ilmiah selama menjabat sebagai kanselir. Hal ini tampak pada kebijakan nasionalnya yang mengacu pada referensi akademis para ahli dan ilmuwan, sehingga ini yang turut mempengaruhi kebijakannya mengatasi Covid-19 (Miller 2020).

Kedua, Merkel berhasil membawa Jerman melewati beberapa krisis besar nasional dan global. Dalam lingkup nasional, Merkel terlibat di kabinet transisi pasca Jerman Bersatu tahun 1990 yang tugasnya sangat berat. Tahun 1994, Merkel menjabat Menteri lingkungan dan tenaga nuklir, salah satu kementerian terprogresif di Eropa. Sejak 2005, Merkel resmi menjadi kanselir dan terdapat tiga krisis besar beruntun yang berhasil diatasinya, mulai isu finansial Eropa 2008-2010, pengungsi Suriah 2015-2019, dan Brexit (British exit) 2016-Januari 2020. Ketiga, kepemimpinan Merkel berhasil mengantarkan Jerman sebagai pemimpin regional Eropa. Hal ini terkait dengan peranan politik domestik Merkel yang berhasil membangun kekuatan ekonomi dan politik Jerman, sehingga mengalahkan kompetitor Eropa lainnya, seperti Prancis dan Inggris.

Pengalaman diatas mengasah kematangan Merkel sebagai politisi dan pemimpinglobal, serta membantunyaketika menghadapikrisis Covid-19. Berdasarkan definisi Hume (2013) tentang modalitas pemimpin, rangkaian pengalaman Merkel tersebut membekalinya 
Germany's Strategy in Handling Covid-19: The Role of National Leadership Strength and The Maximization of Welfare State Continental System Support

dengan wawasan visioner dan komprehensif mengenai urgensi perlindungan negara kepada rakyat dalam masa krisis. Merkel bukan pemimpin orator karismatik, melainkan seorang deep thinker-scientist based, yang berhasil merespons situasi krisis secara tenang dan rasional, dengan tetap mengutamakan pengayoman publik. Menurut Stellzenmüller (2020), Merkel memiliki kemampuan menggabungkan leadership dan politik, sehingga ia sukses sebagai pemimpin cepat tanggap dan akurat (decisive leadership) mengatasi krisis, contohnya ketika Jerman memutuskan dilakukannya TTT melalui detect dan prevention. Meski pada awalnya metode ini banyak dikritik publik, tapi fakta menunjukkan jika strategi prevent dan detection adalah kunci penurunan kasus Covid-19 di Jerman (Bennhold 2020; OECD 2020). Strategi TTT dinilai logis dilakukan di awal kasus, karena mustahil menghentikan langsung penyebaran virus yang hanya bisa diatasi dengan vaksin. Sementara proses penemuan vaksin memerlukan waktu riset tahunan. Metode ini semakin positif bagi Jerman karena Jerman merupakan salah satu negara dengan jumlah laboratorium terbesar di dunia, yang mampu melakukan tes Covid-19 sebanyak 1 juta orang/hari (Spahn 2020).

\section{Pemaksimalan Dukungan Sistem Welfare System dalam Menguatkan Politik Domestik Selama Pandemi}

Sebagai negara yang menerapkan sistem WS Continental, Jerman menempatkan tanggung jawab pembiayaan kesejahteraan sosial seluruh masyarakat kepada pasar kerja dan pengusaha. Negara mengatur regulasi dan distribusi kesejahteraan sosial yang diterima masyarakat. Regulasi dan distribusi tersebut meliputi pendidikan, latihan kerja, perumahan, kesehatan, dan kesejahteraan keluarga. Sehingga melalui sistem WS, peran pasar, negara, serta masyarakat sipil saling berkontribusi menjaga kestabilan ekonomi politik nasional.

Kosonen (1995) menyebut Jerman sebagai penganut sistem WS Continental terprogresif. Sebagai negara dengan penduduk terpadat di Eropa, bukan hal mudah bagi Jerman menjaga kestabilan dan keberlangsungan pembiayaan sistem WS, apalagi di tengah masa pandemi. Kondisi ini relatif berbeda jika 
dibandingkan pembiayaan sistem WS model Scandinavia, yang mana penduduknya lebih sedikit tapi didukung kekuatan ekonomi maksimal dari seluruh warga usia kerja. Namun demikian, Jerman relatif berhasil mempertahankan keberlangsungan sistem WS, dan semakin menguat selama masa krisis Covid-19. Jerman secara tidak langsung juga berperan menguatkan sistem WS di kawasan Eropa yaitu sebagai inisiator program terpadu UE, yang disebut dengan "The Next Generation EU", pada akhir Mei 2020. Program tersebut merupakan paket bantuan ekonomi dan finansial jangka panjang kepada seluruh anggota UE, yang tetap diintegrasikan dengan orientasi awal EU, meliputi isu perubahan iklim dan digitalisasi pasar tunggal UE, yang mana total dananya hampir mencapai EUR 2 triliun (European Commission 2020).

Faktor kesuksesan Jerman menjamin sistem WS terletak pada kestabilan ekonomi nasional yang sebagian besar berasal dari sektor industri sebagai pilar utama ekonomi nasional. Oxford Martin School (Our World in Data, 2020) melaporkan, Jerman menduduki peringkat keempat ekonomi dunia dengan pendapatan per kapita USD 5119. Kestabilan struktur ekonomi politik ini yang semakin menguatkan kepercayaan publikJerman atas kemampuan pemerintahnya mengatasi Covid-19. Sehingga terdapat hubungan erat antara peranan sistem WS Continental dengan keberhasilan pemerintah Jerman menurunkan tingkat penularan dan kematian akibat Covid-19 (Stellzenmüller 2020; Traub dkk. 2020).

Secara umum, upaya pemerintah memaksimalkan dukungan WS Continental tersebut ditunjukkan melalui 3 strategi. Pertama, memberikan kesiapan fasilitas kesehatan maksimal seluruh rakyat melalui fasilitas asuransi kesehatan. Isu kesehatan di negara WS Continental, mendapatkan perhatian serius. Prinsip kesehatan nasional mewajibkan semua warga yang tinggal di Jerman memiliki asuransi kesehatan yang dibayarkan pengusaha/pasar kerja kepada pemerintah atau privat. Jerman mengalokasikan 11 persen dari total gross domestic product (GDP) untuk kebutuhan kesehatan (Our World in Data 2020). Alhasil, Jerman merupakan salah satu negara yang memiliki kualitas dan kapasitas kesehatan terbaik di dunia. Berdasarkan laporan World Bank (2020), di setiap 1000 penduduk, Jerman memiliki ruang rawat inap rumah sakit terbesar 8,3 , ketersediaan dokter 4,2 dan perawat 
13,2. Waktu tunggu pelayanan dokter spesialis dan operasi juga rendah, dan tingkat harapan hidup masyarakat tinggi, mencapai 81 tahun. Sehubungan dengan penanganan Covid-19, kapasitas ruang intensive care unit (ICU) Jerman melebihi negara lain di UE. Jerman memiliki ruang ICU mencapai 56000 unit, dibandingkan Perancis yaitu 9000 unit (Berlin Spectator 2020). Jika banyak negara defisit alat bantu pernafasan (ventilator), Jerman memiliki 25.000 unit dan diproyeksi bertambah 10000 unit baru, sementara Prancis memiliki 5000 unit (Bittner 2020). Alasan utama melimpahnya ventilator di Jerman karena negara tersebut adalah negara produsen terbesar ventilator di dunia.

Kedua, pemberian paket ekonomi darurat tambahan demi menguatkan ekonomi masyarakat selama pandemi. Pada masa sebelum dan selama pandemi, pembiayaan terhadap kesejahteraan sosial masyarakat tetap berlangsung. Kondisinya semakin sulit selama pandemi, tetapi pemerintah pada 23 Maret 2020, meluncurkan paket ekonomi komprehensif sebesar EUR 750 milyar untuk menyubsidi industri kecil, pekerja lepas, perusahaan besar, serta kesejahteraan keluarga (Narlikar 2020). Selain itu, bantuan ekstra pemerintah lainnya meliputi immediate fiscal impulse, dengan anggaran EUR 284,4 milyar (Bruegel 2020). Dibandingkan negara-negara Eropa lainnya, alokasi dana ini merupakan yang paling awal dan terbesar, persentasenya 8.3 persen dari total GDP (Bruegel 2020). Nilai tersebut melampaui Perancis yang mengalokasikan EUR 110 milyar. Alokasi dana darurat Jerman diperuntukkan: kompensasi pemotongan jam kerja akibat wabah (Kurzarbeitgeld) sebesar EUR 23.5 milyar; revitalisasi industri kecil (Soforthilfe) EUR 50 milyar; tunjangan anak (Kindergeld) EUR 4.3 milyar; tambahan tunjangan anak dan wiraswasta EUR 7.7 milyar; stabilitas jaminan sosial 2021 EUR 5.3 milyar; penguatan fasilitas dan asuransi kesehatan EUR 10 milyar; pengembangan fasilitas penitipan anak (Kinderbetreung) EUR 1.2 milyar; dan pemotongan pajak EUR 20 milyar (Bruegel 2020). Paket ekonomi darurat ini adalah terdrastis dan terbesar diputuskan pemerintah pasca PD II, yang akhirnya mengubah Jerman dari negara penganut austerity menjadi big spender dalam waktu singkat (Jakarta Post 2020). Kanselir Merkel menyatakan, jika langkah tersebut sebagai solusi menghindari kerugian lebih besar di masa mendatang. Menurutnya: "It's clear that all of this 
requires a bold response. It's about securing jobs, and keeping the economy running, or getting it going again." (Deutsche Welle 2020).

\section{Simpulan}

Langkah Jerman keluar dari krisis Covid-19 bukanlah sebuah keajaiban dan bersifat tertutup. Formulanya sangat terbuka direplikasi negara lain, yaitu mengandalkan pada konsistensi pola kepemimpinan Merkel di masa krisis serta didukung dengan kekuatan sistem WS. Hanya saja, formula tersebut akan sulit diikuti negara lain ketika negara tersebut tidak memiliki basis kokoh terkait kedua kekuatan tadi, yaitu WS dan kepemimpinan nasional ala Merkel. Walaupun demikian, ada setidaknya 2 hal yang tetap perlu diwaspadai Jerman di tengah keberhasilannya ini. Pertama, pengaruh pertumbuhan ekonomi global yang trennya lesu dan mendadak dapat berdampak serius di level domestik Jerman. Kedua, kekhawatiran gelombang kedua dari pandemi, yang diprediksi terjadi akhir tahun 2020, atau saat musim dingin melanda Eropa. Tetapi dengan bertumpu pada kekuatan kepemimpinan nasional dan sistem WS Jerman, diharapkan semua krisis negara itu teratasi.

\section{Referensi}

\section{Buku dan Bab dalam Buku}

Arenas, Fil J, dkk. 2017. Developing your full range of leadership: Leveraging a transformational approach, Alabama: Air University Press.

Eichhorst, Werner dan Anton Hemerijck. 2008. "Welfare and Employment: A European Dilemma?" Discussion Paper Series, No. 3870, Bonn: Forschungsinstitut zur Zukunft der Arbeit (IZA).

Esping-Andersen, Gøsta. 1990. The Three Worlds of Welfare Capitalism, Princeton University Press. 
Germany's Strategy in Handling Covid-19: The Role of National Leadership Strength and The Maximization of Welfare State Continental System Support

Filippidou, Anastasia. 2014. "Typologies of Leadership: Level of Leadership and Approaches to Transition", in Anastasia Filippidou et al (eds.), The Role of Leadership in Transitional States: The Cases of Lebanon, IsraelPalestine, Pennsylvania: U.S. Army War College-Strategic Studies Institute.

Geneva Centre for the Democratic Control of Armed Forces (DCAF). 2005. States of Emergency. Backgrounder.

Magnusson, Roger. 2017. Advancing the right to health: the vital role of law, Geneva: World Health Organization.

Menachem, Sula. 2015. "Is social services policy based on constraints, ideology or politics?”, International conference on Education, Reflection, Development, 3-4 July, Cluj-Napoca, Romania.

Mills. Clifford W. 2008. Modern World Leaders: Angela Merkel. New York: Chelsea House.

\section{Jurnal dan Jurnal Daring}

Cliffe, Lionel and Robin Luckham. 1999. "Complex Political Emergencies and the State: Failure and the Fate of the State." Third World Quarterly, 20 (1): 27-50.

Ferejohn, John dan Pasquale Pasquino. 2004. "The law of the exception: A typology of emergency powers." International Journal Constitution, 2 (2): 210-239.

Hume, Cameron R. 1997. "Leadership in Crisis Situations." Revista CIDOB d'Afers Internacionals, (38/39): 53-58.

Kosonen, Pekka. 1995. "European Welfare State Models: Converging Trends", International Journal of Sociology, 25 (1): 81-110.

Madison, Bernice. 1970. "The Welfare State: Some Unanswered Questions for the 1970s", Social Service Review, 44 (4): 434-451. 
Scaratti, Chiara, dkk. 2018. "Mapping European Welfare Models: State of the Art of Strategies for Professional Integration and Reintegration of Persons with Chronic Diseases", International Journal Environment Research and Public Health, 15 (4): 781.

\section{Artikel Daring}

Berlin Spectator. 2020. "Corona Crisis in Germany: Intensive Care Capacities Increased Substantially". [daring] https://berlinspectator.com/2020/04/02/coronacrisis-in-germany-intensive-care-capacities-increasedsubstantially/, [diakses 16 Juni 2020].

Binder, Krisztina, dkk. 2020. States of emergency in response to the coronavirus crisis: Situation in certain Member States, Brussel: European Parliamentary Research Service.

Bittner, Jochen. 2020. "Germany Has More Than Enough Ventilators. It Should Share Them: Without health, all is nothing"[daring] https://www.nytimes.com/2020/03/17/ opinion/coronavirus-europe-germany.html, [diakses 20 Juni 2020].

Deutsche Welle. 2020. "Germany's Angela Merkel unveils stimulus package to kickstart economy." [daring] https://www. dw.com/en/germanys-angela-merkel-unveils-stimuluspackage-to-kickstart-economy/a-53677420, [diakses 19 Juni 2020].

Deutsche Welle. 2020. "Merkel: Coronavirus is Germany's greatest challenge since World War II." [daring] https://www. dw.com/en/merkel-coronavirus-is-germanys-greatestchallenge-since-world-war-ii/a-52830797, [diakses 1 Juli 2020].

ECDC. 2020. "COVID-19 situation update for the EU/EEA and the UK." [daring] https://www.ecdc.europa.eu/en/cases2019-ncov-eueea, [diakses 2 Juni 2020]. 
Germany's Strategy in Handling Covid-19: The Role of National Leadership Strength and The Maximization of Welfare State Continental System Support

Euronews. 2020. "Germany's Angela Merkel comes out top in leaders' approval poll for COVID-19 crisis.” [daring] https://www.euronews.com/2020/05/28/germany-sangela-merkel-comes-out-top-in-leaders-approval-pollfor-covid-19-crisis, [diakses 20 Juni 2020].

European Association of Service Providers for Persons with

Disabilities (EASPD). 2014. "Social Welfare Systems Across Europe" [daring] https://www.easpd.eu/sites/ default/files/sites/default/files/SensAge/d4-social welfare_systems_across_europe.pdf, [diakses pada 25 Juni 2020].

European Commission. 2020. "Europe's moment: Repair and prepare for the next generation." [daring] https:// ec.europa.eu/commission/presscorner/detail/en/ ip 20 940, [diakses 10 Juni 2020].

Miller, Saskia. 2020. “The Secret to Germany's COVID-19 Success: Angela Merkel Is a Scientist" [daring] https://www.theatlantic.com/international/ archive/2020/04/angela-merkel-germany-coronaviruspandemic/610225/,[diakses pada 30 Mei 2020].

Narlikar, Amrita. 2020. "The Good, the Bad, and the Ugly: Germany's response to the COVID-19 Pandemic" [daring] https://www.orfonline.org/research/the-good-thebad-and-the-ugly-germanys-response-to-the-covid-19pandemic-66487/, [diakses pada 30 Mei 2020].

OECD. 2020. "OECD Policy Responses to Coronavirus (COVID-19) Testing for COVID-19: A way to lift confinement restrictions" [daring] https://www.oecd.org/coronavirus/ policy-responses/testing-for-covid-19-a-way-to-liftconfinement-restrictions-89756248/, [diakses 30 Juni 2020].

Our World in Data. 2020. "Emerging COVID-19 success story: Germany's strong enabling environment.”[daring] https:// ourworldindata.org/covid-exemplar-germany, [diakses 20 Juni 2020]. 
Sandher, Jeevun dan Hanna Kleider. 2020. "Coronavirus has brought the welfare state back, and it might be here to stay", The Conversation, 24 Juni. [daring] https:// theconversation.com/coronavirus-has-brought-thewelfare-state-back-and-it-might-be-here-to-stay-138564, [diakses 12 Juli 2020].

Spahn, Jens. 2020. "How Germany Contained the Coronavirus." World Economic Forum. [daring] https://www.weforum. org/agenda/2020/05/how-germany-contained-thecoronavirus/, [diakses pada 8 Juni 2020].

Stelzenmüller, Constanze. 2020. Order from Chaos: Germany pulls out the 'bazooka' against the coronavirus - But is it doing enough? March 17, [daring] https://www.brookings. edu/blog/order-from-chaos/2020/03/17/germany-pullsout-the-bazooka-against-the-coronavirus-but-is-it-doingenough/, [diakses pada 2 Juni 2020].

The Bruegel. 2020. "The fiscal response to the economic fallout from the coronavirus." [daring] https://www.bruegel.org/ publications/datasets/covid-national-dataset/\#germany, [diakses 10 Juni 2020].

The Jakarta Post. 2020. "COVID-19: Key points of Germany's mega stimulus." [daring] https://www.thejakartapost.com/ news/2020/06/04/covid-19-key-points-of-germanysmega-stimulus.html, [diakses 10 Juni 2020].

Traub, James dan Paul Von Chamier, "Today's Coronavirus Anger Can Revive Tomorrow's Welfare State.” Foreign Policy. [daring] https://foreignpolicy.com/2020/03/27/ coronavirus-revive-west-welfare-states-solidarity $/$, [diakses 25 Mei 2020].

World Bank. t.t. "Physicians (per 1,0oo people) - Germany." [daring] https://data.worldbank.org/indicator/SH.MED. PHYS.ZS? locations=DE\&most_recent_value desc $=$ true, [diakses 22 Juni 2020].

World Health Organization (WHO). 2020. "Global situation." [daring] https://covid19.who.int/, [diakses pada 8 Juni 
Germany's Strategy in Handling Covid-19: The Role of National Leadership Strength and The Maximization of Welfare State Continental System Support

2020].

\section{Others}

Bennhold, Katrin. 2020. "A German Exception? Why the Country's coronavirus death rate is low," New York Times, 4 April 2020.

Susanto, Siti. 2020. "Covid-19, Babak Baru Politik Global”, Jawa Pos 14 Juni. 